\title{
REVIEW
}

\section{AMP-activated protein kinase pathway and bone metabolism}

\author{
J Jeyabalan, $\mathbf{M}$ Shah, B Viollet ${ }^{\mathbf{1}}$ and $\mathbf{C}$ Chenu \\ Royal Veterinary College, Royal College Street, London NW1 OTU, UK \\ ${ }^{1}$ Institut Cochin, INSERM U1016, CNRS UMR 8104, Universite Paris Descartes, Paris, France \\ (Correspondence should be addressed to C Chenu; Email: cchenu@rvc.ac.uk)
}

\begin{abstract}
There is increasing evidence that osteoporosis, similarly to obesity and diabetes, could be another disorder of energy metabolism. AMP-activated protein kinase (AMPK) has emerged over the last decade as a key sensing mechanism in the regulation of cellular energy homeostasis and is an essential mediator of the central and peripheral effects of many hormones on the metabolism of appetite, fat and glucose. Novel work demonstrates that the AMPK signaling pathway also plays a role in bone physiology. Activation of AMPK promotes bone formation in vitro and the deletion of $\alpha$ or $\beta$ subunit of AMPK decreases bone mass in mice. Furthermore, AMPK activity in bone cells is regulated by the same
\end{abstract}

hormones that regulate food intake and energy expenditure through AMPK activation in the brain and peripheral tissues. AMPK is also activated by antidiabetic drugs such as metformin and thiazolidinediones (TZDs), which also impact on skeletal metabolism. Interestingly, TZDs have detrimental skeletal side effects, causing bone loss and increasing the risk of fractures, although the role of AMPK mediation is still unclear. These data are presented in this review that also discusses the potential roles of AMPK in bone as well as the possibility for AMPK to be a future therapeutic target for intervention in osteoporosis.

Journal of Endocrinology (2012) 212, 277-290

\section{Introduction}

Osteoporosis is a major health problem in our aging society. One in two postmenopausal women will fracture a bone as a result of osteoporosis leading to more than 300000 fragility fractures every year in the UK, which are important causes of morbidity and mortality (Edwards et al. 2007, Harvey et al. 2010). As the population ages, the prevalence of osteoporosis increases sharply and there is consequently a pressing need for the discovery of new molecular targets with potential drug development for prevention and treatment of this disorder. There is increasing evidence that osteoporosis, similarly to obesity and diabetes, could be another disorder of energy metabolism. A close relationship exists between obesity and osteoporosis, two diseases of body constitution that have a genetic predisposition (Rosen \& Bouxsein 2006, Reid 2008). The diagnosis of postmenopausal osteoporosis is largely based on a measurement of bone mineral density (BMD), which is affected by many factors, body weight being the principal one. Positive associations between body weight and BMD have been long demonstrated; loss of body weight being often associated with bone loss and risk for osteoporosis, while gain in body weight increases bone formation due to the skeletal loading (De Laet et al. 2005). However, there are also data showing negative effects of obesity on BMD (Hsu et al. 2006,
Premaor et al. 2011). Body weight is made up of two components, fat mass and lean mass. The relative contribution of these two components to the variation in BMD has been controversial, although in postmenopausal women fat mass has been often shown to be important (Reid et al. 1992, Dytfeld et al. 2011). The intimate association between fat and bone has been extensively described. First, this link is based on the fact that cells which are important in obesity (adipocytes) and osteoporosis (osteoblasts) share a common cell progenitor, the mesenchymal stromal cell (MSC). This cell can differentiate into osteoblasts by expressing the transcription factor RUNX2, while expression of peroxisome proliferator-activated receptor $\gamma 2$ (PPAR $\gamma 2$ ) inhibits osteoblast differentiation and induces MSC differentiation into the adipogenic lineage (Gimble et al. 1996, Ducy 2000). The bone loss in age-related osteoporosis is associated with more adipogenesis and less bone formation (Pei \& Tontonoz 2004). Second, there are direct actions on bone of hormones produced by adipocytes, such as adiponectin and leptin, as well as of hormones released by the pancreas, gut and pituitary (Cornish et al. 1996, 2002, Maccarinelli et al. 2005, Williams et al. 2009). In addition, the recent discovery that leptin can inhibit bone formation through hypothalamic and sympathetic nervous system relays (Ducy et al. 2000, Takeda et al. 2002, Elefteriou et al. 2005) has demonstrated that bone can 
not only be directly affected by hormones which have receptors on bone cells, but can also be influenced by the same hormones acting on receptors in the central nervous system (CNS). The latest demonstration of a feedback control by the skeleton of glucose and fat metabolism through the systemic release of the osteoblast-specific protein osteocalcin (Lee et al. 2007, Ferron et al. 2010, Fulzele et al. 2010) has reinforced the reciprocal relationship between bone and energy metabolism. Bone remodeling, occurring simultaneously in numerous parts of the skeleton, is an energy intensive process and bone constantly needs to balance energy in response to nutrient availability with growth and turnover.

AMP-activated protein kinase (AMPK) has emerged over the last decade as a key sensing mechanism in the regulation of cellular energy homeostasis and is an essential mediator of the central and peripheral effects of many hormones on the metabolism of appetite, fat and glucose (Hardie et al. 2006, Kola et al. 2006, Lage et al. 2008, Steinberg \& Kemp 2009). AMPK senses the AMP/ATP ratio within the cell and, once activated, switches on catabolic pathways (energy generating) and switches off anabolic pathways (energy consuming). It is a key molecule in controlling metabolic diseases such as type 2 diabetes and obesity and is activated by antidiabetic drugs such as metformin and thiazolidinediones (TZDs; Zhou et al. 2001, Fryer et al. 2002, LeBrasseur et al. 2006). Novel findings, described in detail in this review, have shown that AMPK plays a role in bone physiology. There are in vitro studies demonstrating that AMPK modulators regulate bone cell differentiation and function (Kanazawa et al. 2007, 2008, 2009b, Molinuevo et al. 2010, Quinn et al. 2010, Shah et al. 2010, Jang et al. 2011, Mai et al. 2011) and two publications showing that deletions of AMPK $\alpha$ and $\beta$ subunits in mice lead to bone loss in vivo (Quinn et al. 2010, Shah et al. 2010). Furthermore, AMPK activity can be regulated in bone cells by hormones, such as ghrelin and norepinephrine, that regulate food intake and energy expenditure through AMPK activation in the brain and peripheral tissues. The interest in AMPK and bone physiology comes also from the fact that metformin and TZDs have significant and opposing skeletal effects (Gao et al. 2010, Lecka-Czernik 2010, Mai et al. 2011) and the contribution of AMPK to these bone effects is still unclear. Although the elucidation of the importance of AMPK signaling in bone is still in its commencement, the revelation that AMPK activation may affect stimulation of bone formation and bone mass places AMPK signaling as a significant pathway in skeletal physiology.

\section{AMPK, a master sensor of cellular energy status}

\section{Structure and regulation}

There has been a tremendous effort over the last two decades at trying to elucidate the structure of AMPK and its regulation and excellent reviews on the subject exist (Rutter et al. 2003, Carling 2004, Hardie et al. 2006, Viollet et al. 2007, Lage et al.
2008, Oakhill et al. 2009, Steinberg \& Kemp 2009). Briefly, AMPK is a heterotrimeric protein, highly conserved throughout evolution, consisting of three different subunits, $\alpha$ catalytic and regulatory $\beta$ and $\gamma$ (Hardie et al. 1998). In mammals, there are seven genes encoding subunits $(\alpha 1, \alpha 2$, $\beta 1, \beta 2, \gamma 1, \gamma 2, \gamma 3)$, that can form 12 possible AMPK heterotrimers, which exhibit differences in subcellular localization and regulation (Hardie 2007). At the molecular level, the $\alpha$ catalytic subunit contains the conventional serine/ threonine protein kinase domain as well as the autoinhibitory sequence, the $\beta$ subunit contains a glycogen-binding domain and a tethering domain for $\alpha$ and $\gamma$ subunits, while the $\gamma$ subunit contains four cystathionine- $\beta$-synthase sequence repeats, which are responsible for the binding of regulatory nucleotides (McBride \& Hardie 2009, Oakhill et al. 2009). AMPK regulates the activities of many target proteins controlling different aspects of metabolism and therefore the regulation of its activity in the cell involves complex signaling pathways and sensing mechanisms. AMPK is activated by the binding of AMP to the regulatory $\gamma$ subunit, which overall promotes the phosphorylation of Thr-172 within $\alpha$ catalytic subunit by upstream kinases, protects against the dephosphorylation of Thr-172 by protein phosphatases and causes allosteric activation (for reviews see Carling et al. (2008) and Hardie (2008)). To date, three known upstream AMPK kinases have been described, the tumor suppressor kinase LKB1, calmodulin kinase kinase (CaMKK) and transforming growth factor- $\beta$-activated kinase (TAK1), but their physiologic roles are not always very clear (Woods et al. 2003, Carling et al. 2008, Lage et al. 2008, Oakhill et al. 2009). Thus, increases in the cellular AMP/ATP ratio cause a dramatic and progressive activation of AMPK. Recent evidence demonstrates that ADP can also regulate AMPK activation by protecting AMPK from dephosphorylation (Xiao et al. 2011). In addition, AMPK activity can be modulated independently of AMP by activation of CaMKK $\beta$ due to increasing intracellular $\mathrm{Ca}^{2+}$ levels (Hawley et al. 2005, Tamas et al. 2006, Sanders et al. 2007) and by ubiquitination and degradation (Qi et al. 2008). A simplified cartoon illustrating the structure and regulation of AMPK activity is shown in Fig. 1.

\section{Function}

In mammals, AMPK plays the role of an intracellular sensor that modulates the energy balance within the cell. It is activated by an increasing cellular AMP/ATP ratio, a measure that the cell experiences a decrease in energy caused by metabolic stresses that interfere with ATP production or consumption such as exercise, hypoxia, and muscle contraction. Once activated, AMPK switches on pathways that generate ATP and switches off ATP-consuming pathways that are not essential for short-term cell survival to restore the AMP/ATP ratio (Kahn et al. 2005, Hardie 2007). AMPK regulates many metabolic pathways in peripheral tissues by phosphorylating metabolic enzymes such as enzymes involved 


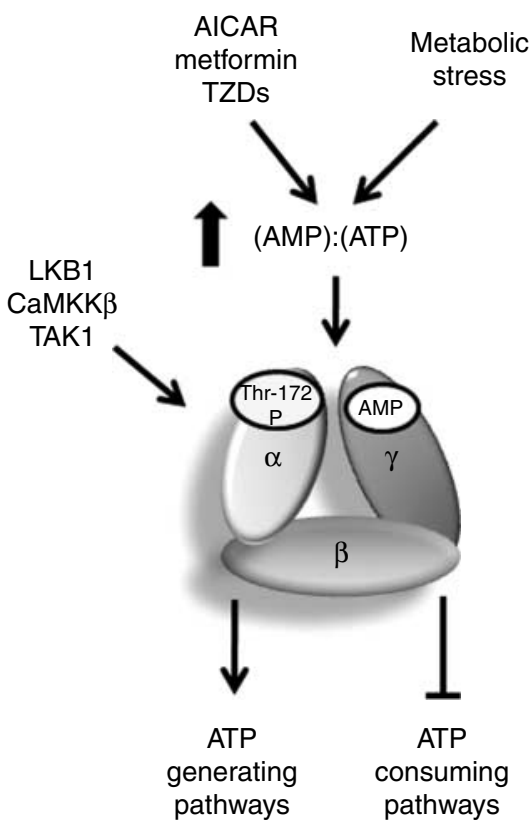

Figure 1 Structure and regulation of AMPK. AMP-activated kinase (AMPK) is a heterotrimeric protein consisting of three different subunits, $\alpha$ catalytic and regulatory $\beta$ and $\gamma$. AMPK is activated by the binding of AMP to the regulatory $\gamma$ subunit that promotes phosphorylation of Thr-172 within $\alpha$ catalytic subunit by upstream kinases (such as the tumor suppressor kinase LKB1, calmodulin kinase kinase (CaMKK), and transforming growth factor- $\beta$-activated kinase (TAK1)) and causes allosteric activation. Increases in cellular AMP/ATP ratio caused by cellular stress or drugs (AICAR, metformin, and TZDs) activate AMPK, which maintains energy homeostasis by switching on catabolic pathways that produce ATP (energy generating) and switching off anabolic pathways (energy consuming). At the whole-body level, this is translated into changes in energy expenditure and feeding.

in lipid, glucose, and glycogen metabolisms (Hardie \& Pan 2002, Carling et al. 2003, Hardie 2003, 2004, 2008, Rutter et al. 2003, Hardie \& Sakamoto 2006, Viollet et al. 2006, 2009a, Steinberg \& Jorgensen 2007, Canto \& Auwerx 2010). In addition to its direct acute effect via phosphorylation of metabolic enzymes, AMPK has also longer term indirect effects by regulating gene transcription, affecting expression of genes that encode those metabolic processes (McGee \& Hargreaves 2008, Scott et al. 2009). In general, AMPK will promote energy production and upregulate the transcription of catabolic genes such as the glucose transporter 4 (GLUT4) as well as genes involved in mitochondrial biogenesis such as PPAR $\gamma$ coactivator $1 \alpha$ (PGC1 $\alpha$; Holmes et al. 1999, Zong et al. 2002). AMPK will also limit energy utilization to ensure cell survival, so activation of AMPK will mediate cell cycle arrest, inhibit growth and suppress protein synthesis through downregulation of mechanistic target of rapamycin (MTOR; also known as mammalian target of rapamycin) signaling (Bolster et al. 2002, Jones et al. 2005, Motoshima et al. 2006, Greer et al. 2007). AMPK activation also regulates genes involved in immunity (interleukin-2, T-cell receptor) and vascularization (vascular endothelial growth factor, neuronal nitric oxide synthase; Levine et al. 2007, Reihill et al. 2007, Mayer et al. 2008). AMPK phosphorylation targets include cytoplasmic and nuclear proteins, as AMPK activation is usually confined to the cytoplasm in response to energy stress but can be observed in the nucleus in response to calcium elevation (Tsou et al. 2011). The exact mechanisms regulating AMPK subcellular localization are not completely understood, but a recent study has identified a nuclear export signal in the C-terminal domain of catalytic $\alpha$ subunit of AMPK (Kazgan et al. 2010). They demonstrate that AMPK $\alpha$ is imported into the nucleus via a Ran-GDP-dependent pathway but translocation to the nucleus can be regulated by exercise, cellular stress, and circadian rhythms. In addition to its effect on cellular energy balance in peripheral tissues, AMPK also plays a key role in the control of whole-body energy homeostasis by integrating, at the hypothalamic level, nutrient and hormonal signals that regulate food intake and energy expenditure (Andersson et al. 2004, Minokoshi et al. 2004, Dzamko \& Steinberg 2009, Hardie 2011). AMPK has indeed been shown to be a major regulator of food intake by acting in hypothalamic neurons and modulating the hypothalamic fatty acid metabolic pathway (Lopez et al. 2007). Fasting and orexigenic signals increase AMPK activity in several hypothalamic regions, while feeding and anorectic signals inhibit it (Kola et al. 2005, Gao et al. 2007, Lopez et al. 2008). Nutrient- and hormone-induced alterations in AMPK hypothalamic activity have been shown to correlate with changes in neuropeptide expression in hypothalamic nuclei, indicating that AMPK activation in the hypothalamus links whole-body energy balance with neurotransmitter signaling pathways (Lee et al. 2005, Lage et al. 2008). A possible role for hypothalamic AMPK in the control of obesity is the focus of increasing interest.

\section{AMPK is a mediator of the metabolic effects of many hormones}

Many of the metabolic effects of peripheral hormones are mediated by AMPK, which plays a central role in the endocrine system (for reviews see Kahn et al. (2005), Kola et al. (2006), and Lage et al. (2008), Dzamko \& Steinberg (2009) and Lim et al. (2010)). Leptin was the first hormone described to activate AMPK in the skeletal muscle, leading to inhibition of fatty acid synthesis and increase in fatty acid oxidation and glucose uptake (Minokoshi et al. 2002). Both phosphorylation of acetyl-CoA carboxylase (ACC) by AMPK $\alpha 2$ and stimulation of $\operatorname{PPAR} \alpha$ transcription are responsible for fatty acid oxidation by leptin in skeletal muscle. Leptin also stimulates fatty acid oxidation via AMPKdependent pathways in the heart (Lee et al. 2004). In contrast to its stimulatory effect on AMPK activation in peripheral tissues, leptin inhibits AMPK activity in the hypothalamus, leading to an increase in appetite (Andersson et al. 2004, Minokoshi et al. 2004). Another hormone produced by the adipocytes is adiponectin, which improves glucose uptake and fatty acid oxidation in muscle, reduces hepatic glucose 
production and enhances insulin sensitivity. AMPK activation has been shown to mediate all these effects of adiponectin on peripheral tissues (Yamauchi et al. 2002, Huypens et al. 2005). Adiponectin also plays an important role in the heart where it protects it from ischemia-reperfusion injury through an AMPK-dependent mechanism (Shibata et al. 2005). Ghrelin is a hormone produced by the gut that is also very important for the control of feeding. It has orexigenic effects mediated by AMPK activation in the hypothalamus (Kola et al. 2005). Ghrelin also inhibits AMPK activity in the liver and adipose tissue, upregulating gluconeogenesis and lipogenesis, but increases AMPK activity in the heart (Korbonits et al. 2004). In addition to mediating the actions of hormones on the CNS and peripheral tissues, AMPK also integrates the effects of several other factors, such as cytokines and neuromediators (van Thuijl et al. 2008).

\section{Main drugs that are $A M P K$ activators}

Besides, the physiological activators (muscle contraction) and pathological stresses (heat, glucose deprivation, and hypoxia), a variety of drugs and xenobiotics activate AMPK (Oakhill et al. 2009, Zhou et al. 2009, Hawley et al. 2010, Mantovani \& Roy 2011). The first drug shown to activate AMPK was the nucleoside 5-aminoimidazole-4-carboxamide ribonucleoside (AICAR; Corton et al. 1995). It is a synthetic AMP mimetic compound that is phosphorylated in cells to AICA riboside monophosphate (ZMP). AICAR was shown to reverse many metabolic defects in animal models of insulin resistance and is still the most widely used agent to activate AMPK (Zhou et al. 2009). However, due to the fact that ZMP is an AMP mimetic, it can have AMPK-independent effects. It was shown, for example, that AICAR binds and inhibits the heat shock protein (Hsp90; Tomaselli et al. 2010) and ZMP has been hypothesized to be a toxic metabolite in the neurological disorder Lesh-Nyhan disease (Lopez 2008). In 2001, it was reported that the drug metformin, which belongs to the class of biguanides and is the most commonly prescribed oral antidiabetic drug in the USA, activates AMPK (Zhou et al. 2001, Hawley et al. 2010). Similarly, although AMPK activation is responsible for many of its cellular actions, metformin can also have AMPK-independent effects (Foretz et al. 2010). Interestingly, it was later shown that another class of antidiabetic drugs, the TZDs, also stimulates AMPK (Fryer et al. 2002), although the main therapeutic target of TZDs is the nuclear receptor PPAR $\gamma$. Metformin and TZDs were shown to indirectly activate AMPK by increasing the intracellular AMP/ATP ratio and subsequently making AMPK a better substrate for LKB1, one of the AMPK upstream kinase (Carling et al. 2008). Many natural products derived from traditional medicine that were claimed to have beneficial effects in diabetes and cancer can also activate AMPK. They include resveratrol, epigallocathechin gallate, berberine, and quercitine (Mooney et al. 2008, Turner et al. 2008, Zhou et al. 2009). Recent years have shown the development of novel pharmacological agents that can modulate AMPK directly with the hope that these compounds will be promising in the treatment of metabolic disorders. Two new small molecules were shown to directly activate AMPK in vivo and in vitro. The first one is the compound A-79662 developed by Abbott Laboratories that belongs to the thienopyridone family. It seems a more promising selective activator of AMPK (Zhao et al. 2007, Scott et al. 2008), although it was shown to inhibit the function of the $26 \mathrm{~S}$ proteasome by an AMPK-independent mechanism (Moreno et al. 2008). The second compound is the thiazolidinone PT1 from the Shanghai Institute of Materia Medica (Pang et al. 2008). The mechanisms of action of these two compounds are described in these reviews (Zhang et al. 2009, Fogarty \& Hardie 2010).

\section{Role of AMPK in bone}

\section{Subunit expression and AMPK regulation in bone cells}

The different AMPK subunits have been shown to have differential tissue-specific expression and activation (Steinberg \& Kemp 2009). Most AMPK subunits isoforms are expressed in bone tissue and bone cells, indicating possible combinations to form different AMPK complexes. In contrast with skeletal muscle, heart, and liver, and similar to adipose tissue, $\alpha 1$ subunit is the dominant catalytic isoform expressed in bone, suggesting that it may play a major function in skeletal metabolism. Using both RT-PCR and western blot analysis, it was shown that $\alpha 1$ subunit is highly expressed in bone tissue, primary osteoblasts and osteoclasts as well as in osteoblastic cell lines (Kim et al. 2008, Kasai et al. 2009, Quinn et al. 2010, Shah et al. 2010). In contrast, the $\alpha 2$ subunit has a very low expression in osteoblasts and bone tissue and is not expressed in ROS 17/2.8 cells and osteoclasts (Quinn et al. 2010, Shah et al. 2010). While both $\beta 1$ and $\beta 2$ subunits are similarly expressed in bone, the $\gamma$ subunit also shows differential expression in bone tissue and cells. The $\gamma 1$ subunit is the major $\gamma$ isoform in bone tissue and bone cells, $\gamma 2$ being poorly expressed in osteoblasts and not expressed in osteoclasts while $\gamma 3$ has only been identified in ROS 17/2.8 osteoblastic cells (Quinn et al. 2010, Shah et al. 2010).

Several studies have demonstrated that the cell-permeable AMP analog AICAR can activate AMPK in primary osteoblasts and osteoblastic cell lines (Kim et al. 2008, Shah et al. 2010), as well as in osteoclasts and in the macrophagelike RAW264.7 cell line (Quinn et al. 2010). It causes a large and sustained increase in both AMPK $\alpha$ phosphorylation at Thr-172 and AMPK activation measured by an in vitro peptide phosphorylation assay. Results on osteoblastic MC3T3-E1 cell line are however divergent as AICAR was reported to either phosphorylate AMPK in those cells (Kanazawa et al. 2007) or to fail to induce sustained phosphorylation of AMPK $\alpha$ (Kasai et al. 2009). Another AMPK agonist, metformin, has uniformly been shown to be a potent stimulator of AMPK activation in bone marrow 
progenitor cells (BMPC; Molinuevo et al. 2010), primary osteoblasts (Shah et al. 2010), MC3T3-E1 cells (Kanazawa et al. 2008, Kasai et al. 2009), ROS 17/2.8 cells (Shah et al. 2010), and primary bone marrow macrophages (Lee et al. 2010). The downstream target of AMPK, ACC, is also phosphorylated in primary osteoblasts by AICAR and metformin. There are not many AMPK inhibitors. One of them is compound $\mathrm{C}$ that has been shown to decrease AMPK $\alpha$ phosphorylation in primary osteoblasts and ROS $17 / 2.8$ cells (Shah et al. 2010). However, although compound $\mathrm{C}$ is described as an AMPK inhibitor, it can inhibit the AKT/ MTOR pathway independently of AMPK (Vucicevic et al. 2011) and is also known as dorsomorphin that inhibits bone morphogenetic protein (BMP) signaling (Yu et al. 2008). Both the BMP and the AKT/MTOR pathways are very important for osteoblastic differentiation and bone formation (Peng et al. 2003, Cao \& Chen 2005, Sugatani \& Hruska 2005, Wan \& Cao 2005, Mukherjee \& Rotwein 2009).

The hormonal regulation of AMPK activation in bone has not been extensively studied. Adiponectin, which increases osteoblast proliferation and differentiation (Oshima et al. 2005) but has controversial effect on bone mass in vivo (Williams et al. 2009), can stimulate AMPK phosphorylation in MC3T3-E1 osteoblastic cells (Kanazawa et al. 2007). We showed that AMPK phosphorylation and activity in ROS17/2.8 cells was stimulated by ghrelin (Shah et al. 2010), a hormone known to stimulate osteoblast differentiation and function (Maccarinelli et al. 2005, van der Velde et al. 2008). Dexamethasone, a synthetic glucocorticoid that has been shown to induce osteoblastic differentiation and bone formation in several culture systems (Delany et al. 1994), stimulates AMPK phosphorylation in primary osteoblasts (unpublished results, M Shah, J Jeyabalan, B Viollet \& C Chenu). We also examined the effect of propranolol, a $\beta$-adrenergic receptor antagonist that stimulates bone formation in vivo (Elefteriou et al. 2005), on AMPK activity in ROS $17 / 2.8$ cells and our results demonstrate that propranolol enhances AMPK phosphorylation and activity in those cells (Shah et al. 2010). Cytokines may also modulate AMPK activation (Steinberg et al. 2009) and RANKL was shown to activate AMPK phosphorylation in bone marrow-derived osteoclastic cells (Lee et al. 2010). In addition, other non-hormonal factors can modulate AMPK activation in bone cells and, for example, ultrasound induces AMPK phosphorylation in human fetal osteoblastic cells (Hou et al. 2008). This neuroendocrine regulation of AMPK in osteoblasts clearly suggests a link between AMPK activation and osteoblast function.

\section{Effect of AMPK activation on bone cell activities in vitro and in vivo}

Several studies have examined the effects of AMPK activators on osteoblast differentiation and function in vitro and most of them have used MC3T3-E1 mouse calvaria-derived cells. It was shown that AICAR and metformin both cause a direct osteogenic effect in MC3T3-E1 cells (Cortizo et al. 2006,
Kanazawa et al. 2007, 2008, 2009b, Jang et al. 2011). These actions include a dose-dependent increase in cell proliferation, type I collagen production, alkaline phosphatase (ALP) activity, and mineral deposition. These osteogenic effects could be mediated by an increase in COX-2 and endothelial nitric oxide synthase, in the activity of extracellular signalregulated kinases $1 / 2$ as well as in BMP2 production (Hou et al. 2008). Metformin was also found to regulate small heterodimer partner in MC3T3-E1 cells, an orphan nuclear receptor that stimulates osteoblastic bone formation by interacting with the transcription factor RUNX2 (Jang et al. 2011). The action of metformin on bone marrow mesenchymal cell progenitors has also been investigated and metformin similarly causes an increase in ALP activity, collagen synthesis, osteocalcin production, and extracellular calcium deposition in vitro, possibly by increasing the expression of RUNX2 (Molinuevo et al. 2010). We and others (Shah et al. 2010, Zhen et al. 2010) have used primary osteoblasts derived from rat calvaria to study the effect of AMPK activation in an in vitro model of bone formation in which the production and the mineralization of a bone matrix, can be assessed quantitatively (Utting et al. 2006). We confirmed in this model that both AICAR and metformin, at doses ranging between 0.5 and $100 \mu \mathrm{M}$, dose-dependently stimulated bone nodule formation, while AMPK inhibitor compound C dose-dependently reduced bone formation (Shah et al. 2010). In this model, metformin also markedly increased cell proliferation and ALP activity (Zhen et al. 2010), while AICAR preferentially stimulated ALP activity after 14 days of culture, during the mineralizing phase (Shah et al. 2010). When primary osteoblasts were co-treated with AICAR and compound C, compound C suppressed the stimulatory effect of AICAR on bone nodule formation, supporting a role for AMPK activation in bone formation. However, these results are in contrast to the study showing that osteoblast differentiation is functionally associated with decreased AMPK activity, measured by phosphorylation levels of AMPK $\alpha$ subunit (Kasai et al. 2009). We found a similar decrease in baseline AMPK activity with time during osteoblast differentiation. This may be due to the high energy requirements and therefore elevated ATP contents observed in mature osteoblasts during bone matrix production and mineralization. Osteoblast differentiation was previously shown to coincide with changes in cellular metabolism and mitochondrial activity (Komarova et al. 2000). In agreement with this, our results demonstrate that when AICAR and metformin were added to primary osteoblasts at specific stages of their differentiation, although they always induced AMPK phosphorylation, their effects were more potent at later stages of osteoblastic differentiation (unpublished results, M Shah, J Jeyabalan, B Viollet \& C Chenu).

Fewer studies have investigated the relationship between AMPK activation and bone resorption. Compound $\mathrm{C}$ has been shown to potentiate bone resorption, via inhibition of AMPKa1 in bone marrow-derived osteoclast precursors, AMPK acting as a negative regulator of RANKL (Lee et al. 2010). In agreement with those results, adiponectin was 
demonstrated to inhibit the stimulation by tumour necrosis factor $\alpha$ and RANKL of the master transcriptional factor of RANKL-induced osteoclastogenesis, the nuclear factor of activated $\mathrm{T}$ cells $\mathrm{c}$, through the AMPK signaling pathway (Yamaguchi et al. 2008). Metformin was very recently shown to reduce osteoclast differentiation and activity by stimulating osteoprotegerin (OPG) and inhibiting RANKL mRNA and protein expression in osteoblasts (Mai et al. 2011). Conflicting results were however shown by Quinn et al. (2010) who demonstrated that AICAR treatment in male mice stimulates bone loss and bone turnover with elevated rates of both bone formation and bone resorption (Quinn et al. 2010). The high bone resorption was due to an increase in osteoclast number. While the authors of this study confirmed that AICAR stimulates osteoclast formation in vitro, a result in contradiction with the previously mentioned in vitro studies demonstrating that AMPK activation suppresses osteoclast activity, they however showed that AICAR's effect was independent of AMPK signaling (Quinn et al. 2010). The effect of metformin on bone mass in vivo was also poorly studied, but two recent studies indicate that metformin reduces the bone loss induced by ovariectomy (OVX), in part through increasing bone formation via induction of osteoblast genes such as Runx2 and Lrp5 (Gao et al. 2010) and by reducing RANKL and stimulating OPG expression in osteoblasts (Mai et al. 2011).

\section{Bone phenotypes of mice with deletions of AMPK subunits}

The most striking evidence for a role of AMPK signaling in the regulation of bone mass came from genetic studies which analysed bone mass in mice with deletions of AMPK $\alpha$ and $\beta$ subunits. In many mouse strains AMPK catalytic subunits are genetically redundant as single $\alpha 1$ or $\alpha 2$ knockouts $(\mathrm{KO})$ are viable, yet double KOs are embryonically lethal. The metabolic exploration of AMPK $\alpha 1$ and $\alpha 2 \mathrm{KO}$ has revealed distinct physiologic roles for these two catalytic subunits (for a review of these KOs, see Viollet et al. (2003a)). Daval et al. (2005) reported no difference in body mass in AMPK $\alpha 1 \mathrm{KO}$ mice, but these mice had less fat. Energy expenditure and food intake were not modified in AMPK $\alpha 1$ KO mice (Viollet et al. 2009b). These mice also had normal glucose tolerance and normal response to insulin (Jorgensen et al. 2004). In contrast to the lack of detectable metabolic phenotype of AMPK $\alpha 1 \mathrm{KO}$, whole-body AMPK $\alpha 2$ deletion resulted in mild insulin resistance and impaired glucose tolerance associated with insulin secretory defect (Viollet et al. 2003 b, Jorgensen et al. 2004). We analyzed bone mass in both AMPK $\alpha 1$ and $\alpha 2 \mathrm{KO}$. In agreement with the very low expression of $\alpha 2$ in bone, we found no changes in bone mass in tibia from AMPK $\alpha 2 \mathrm{KO}$ mice compared with wild-type (WT) mice (Shah et al. 2010). In contrast, both cortical and trabecular bone compartments were smaller in the AMPK $\alpha 1$ $\mathrm{KO}$ mice compared with the WT mice. AMPK $\alpha 1^{-/-}$mice showed dramatic decrease in trabecular bone volume $(-39 \cdot 2 \%)$, trabecular number $(-31 \cdot 1 \%)$, and trabecular thickness $(-12 \cdot 2 \%)$ compared with WT mice. The cortical indexes were also decreased in mice lacking AMPK $\alpha 1$, but no change in bone length was observed in those mice (Shah et al. 2010). Similarly, Quinn et al. (2010) showed that germline deletions of either AMPK $\beta 1$ or $\beta 2$ subunit result in reduced trabecular bone density and mass. Surprisingly, their bone histomorphometric analysis revealed no difference in osteoclast and osteoblast numbers between WT and AMPK $\beta 1$ or $\beta 2 \mathrm{KO}$ groups, suggesting that AMPK may influence bone cell functions other than bone cell differentiation. To investigate whether bone turnover could be stimulated in the absence of AMPK $\alpha 1$ subunit, we subjected WT and AMPK $\alpha 1^{-/-}$mice to catabolic (OVX) and anabolic (intermittent PTH administration) hormonal challenges. AMPK $\alpha 1^{-/-}$mice displayed a decreased bone loss after OVX in the trabecular compartment compared with WT mice. Similarly, although PTH increased cortical and trabecular bone indexes in both WT mice and AMPK $\alpha 1^{-/-}$ mice, AMPK $\alpha 1^{-/-}$mice showed a smaller increase in bone mass in response to $\mathrm{PTH}$ treatment compared with WT mice (Shah et al. 2011). The demonstration that AMPK $\alpha 1^{-/-}$ mice are less affected by catabolic and anabolic changes in bone turnover induced by OVX and $\mathrm{PTH}$, respectively, suggests that AMPK activation can influence the hormonal regulation of bone remodeling.

\section{Possible targets and metabolic pathways regulated by AMPK in bone}

The mechanisms linking AMPK activation to bone cell differentiation and bone mass remain mainly unknown. AMPK influences major metabolic pathways and it would seem intuitive that some of these pathways are also regulated by AMPK in bone cells. Since AMPK was recently shown to promote $\beta$-catenin transcription through phosphorylation of class IIa histone deacetylase 5 (Zhao et al. 2011), it is therefore probable that AMPK regulates osteoblast differentiation through crosstalk with the Wnt/ $\beta$-catenin pathway. Another pathway that is important for both osteoblast differentiation and osteoclastic bone resorption is the mevalonate pathway (Kanazawa et al. 2009a, Dunford 2010, Rogers et al. 2010, Yamashita et al. 2010). This pathway is required for the prenylation of regulatory proteins such as Ras and Rho GTPases that play a pivotal role in the regulation of numerous key cellular processes. Statins, drugs that inhibit the HMGCoA reductase enzyme in the mevalonate pathway, stimulate osteoblast differentiation and bone formation in rodents both in vitro and in vivo (Horiuchi \& Maeda 2006). Since statins may exert their vasculoprotective effects through activation of AMPK (Ewart \& Kennedy 2011) and can phosphorylate AMPK in vitro (Rossoni et al. 2011), it is possible that AMPK signaling may also mediate some of the skeletal effects of statins. AMPK can indeed modulate the mevalonate pathway through repression of $\mathrm{HMG}-\mathrm{CoA}$ reductase (Oliaro-Bosso et al. 2009) and could therefore influence this pathway in bone cells. Bisphosphonates, the widely prescribed 
antiosteoporosis drugs, target the mevalonate pathway as well by inhibiting farnesyldisphosphate and geranylgeranyldisphosphate synthase (Russell et al. 2008, Rogers et al. 2010). Finally, it is also likely that AMPK activation is involved in the relationship between fat and bone in the marrow by affecting expression and/or activity of transcription factors essential for osteoblastic and adipocytic lineage commitments of MSC progenitors as discussed in the following section.

\section{AMPK and the relationship between bone and fat}

Osteoblasts and adipocytes arise from a common precursor, the pluripotent MSC. Both cell types are found in the bone marrow and a number of linage-specific transcription factors and multiple extracellular and intracellular signaling pathways regulate differentiation into osteoblast or adipocyte lineages. Wnt/ $\beta$-catenin signaling pathway and RUNX2 induce osteoblastogenesis while inhibiting adipogenesis, whereas $\operatorname{PPAR} \gamma$ plays a pivotal role in adipogenesis while inhibiting osteoblastogenesis (Lecka-Czernik et al. 1999, Ahdjoudj et al. 2004, Kang et al. 2007, Takada et al. 2007). This reciprocal regulation of PPAR $\gamma$ and RUNX2 underlies the lineage commitment of MSC progenitors to adipocytes or osteoblasts and consequently the age-related increase in bone marrow fat and bone loss (Pei \& Tontonoz 2004). The activation of PPAR $\gamma 2$ using rosiglitazone was shown to cause differentiation of bone marrow-derived MSC into adipocytes while blocking osteoblast differentiation via suppression of RUNX2 (Gimble et al. 1996). In addition, activation of PPAR $\gamma 2$ in cells of the osteoblast lineage has been shown to convert them to terminally differentiated adipocytes. In contrast, PPAR $\gamma 1$ isoform induces osteoclastogenesis from hematopoietic stem cell pool and bone resorption by regulating c-FOS expression and increasing the expression of RANKL (Lazarenko et al. 2007, Wan et al. 2007). Interestingly, AMPK has been shown to phosphorylate $\beta$-catenin, suppress PPAR $\gamma$ expression, and reduce adipogenesis in vitro (Zhao et al. 2010). Moreover, it can modify PPAR $\gamma$ activity by directly phosphorylating PPAR $\gamma$ coactivators (Leff 2003, Jager et al. 2007). Since AMPK was also shown to affect RUNX2 expression in BMPC (Molinuevo et al. 2010), AMPK activation could therefore be a signal for the skeleton to sense energy status and initiate adipogenesis or osteoblastogenesis depending on energy needs. It could also be an indication for the skeleton to instigate the appropriate bone remodeling response associated either with augmentation of energy-producing processes or decreased energycosting processes. Changes in metabolic pathways indeed occur during bone cell differentiation and function to allow high ATP generation for bone matrix production and mineralization, as well as for bone resorption (Komarova et al. 2000, Kim et al. 2007). The potential role of AMPK in the regulation of bone homeostasis is shown in Fig. 2.

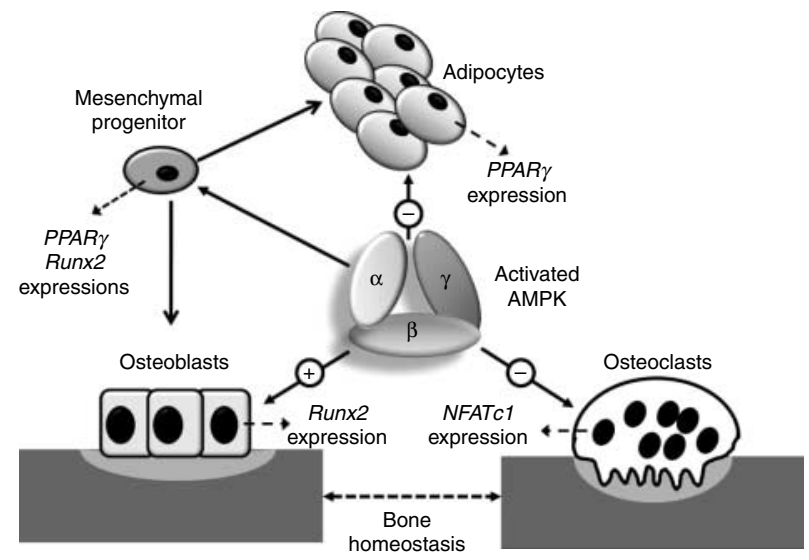

Figure 2 AMPK and the regulation of bone homeostasis. Bone homeostasis is maintained by the balance between osteoblastic bone formation and osteoclastic bone resorption. Activation of the AMPK pathway stimulates osteoblast differentiation and bone formation via enhancing the osteoblast-specific transcription factor RUNX2. Activated AMPK can also lead to the inhibition of osteoclast formation and bone resorption possibly via suppression of the nuclear factor of activated T cells c1 (NFATc1). Activation of AMPK inhibits adipogenesis by reducing the expression of major genes involved in adipogenesis, including PPAR $\gamma$. The AMPK signaling pathway may also determine adipocyte and osteoblast differentiation from mesenchymal progenitors by regulating the expressions of Runx2 and PPAR $\gamma$.

\section{AMPK and the skeletal effects of antidiabetic drugs}

AMPK is activated by antidiabetic drugs such as metformin and TZDs. Both drugs have complementary mechanisms of action to control glycemia, TZDs directly target insulin resistance while metformin reduces hepatic glucose production. TZDs, such as rosiglitazone and pioglitazone, significantly improve insulin sensitivity but at the cost of increased marrow adiposity and bone loss (de Paula et al. 2010). Although TZDs function mainly by activating $\operatorname{PPAR} \gamma$, they can also rapidly activate AMPK in mammalian tissues and cells independently of their effect on PPAR $\gamma$ mediated gene transcription (LeBrasseur et al. 2006). Furthermore, TZDs possibly affect AMPK indirectly by causing release of adiponectin (Maeda et al. 2001) leading to activation of AMPK and reduction in glucose production (Lee \& Kim 2010). While type 2 diabetes itself imposes a higher risk for fractures, there is also growing clinical evidence that TZD treatment decreases BMD and increases incidence of fractures (Grey et al. 2007, Grey 2008, 2009, Lecka-Czernik 2010). As mentioned previously, rosiglitazone has been shown to increase adipogenesis in BMPC and to decrease osteoblastogenesis (Benvenuti et al. 2007, Molinuevo et al. 2010). In addition, several in vivo studies have demonstrated that administration of TZDs to rodents induces adverse skeletal effects, including a decrease in total body BMD, trabecular bone volume and osteoblast number, while it increases the number of marrow adipocytes (Rzonca et al. 2004, Soroceanu et al. 2004, Ali et al. 2005, Li et al. 2006, 
Lazarenko et al. 2007). The published literature suggests that the effects of TZDs on bone may however vary depending on the strain/sub-strain of mice, gender, age, dose, and duration of treatment, as well as the hormonal status and the anatomical location (Ackert-Bicknell et al. 2009). For example, female rats treated with rosiglitazone did not exhibit any adverse effect on bone, while ovariectomy in these rats led to a significant rosiglitazone-induced bone loss, indicating that TZDs may enhance the bone loss induced by estrogen deprivation (Sottile et al. 2004). This is in agreement with a recent study in transgenic mice overexpressing PPAR $\gamma$ in osteoblasts, in which the bone loss in female became evident only after ovariectomy, although the male mice also exhibited reduced bone mass (Cho et al. 2011). Clinical studies have also shown that TZDs have greater effects on bone loss (Berberoglu et al. 2010) and risk of fractures (Kahn et al. 2008) in postmenopausal women with type 2 diabetes than in males. Furthermore, bones of young, growing mice were shown to be less affected than those of adult and older mice (Lazarenko et al. 2007). The involvement of AMPK in the mechanism of action of TZDs in bone has not yet been investigated, but rosiglitazone has been shown to ameliorate alcoholic fatty liver via the adiponectin/SIRT1/AMPK pathway and to indirectly increase AMPK activity by inhibiting complex I of the respiratory chain to result in increased AMP/ATP ratio (Lim et al. 2010, Shen et al. 2010). It is also well known that PPAR activity can be modulated by phosphorylation (Burns \& Vanden Heuvel 2007); phosphorylation of PPAR $\gamma$ coactivator, $\mathrm{p} 300$, by AMPK was shown to reduce its interaction with PPAR $\gamma$ and to repress transcriptional activation function of the receptor (Yang et al. 2001, Leff 2003). Therefore, we cannot exclude that PPAR $\gamma$ is also a transcriptional target of AMPK as shown for PPAR $\alpha$ (McGee \& Hargreaves 2008).

In contrast, metformin induces an osteogenic effect in vivo and in vitro, possibly mediated via RUNX2 and activation of AMPK (Cortizo et al. 2006, Gao et al. 2010, Lee et al. 2010, Molinuevo et al. 2010, Zhen et al. 2010). Co-treatment of BMPC with metformin partially inhibits the adipogenic action of rosiglitazone (Molinuevo et al. 2010). Experimental studies have shown that metformin prevents bone loss in ovariectomized rats, reducing RANKL expression in osteoblasts and therefore inhibiting osteoclast differentiation and activity (Mai et al. 2011). In addition, metformin treatment has been shown to stimulate bone healing in a craniotomy defect model in both control and diabetic rats (Molinuevo et al. 2010). The effect of metformin on bone in humans has been poorly studied, but due to the safety problems of rosiglitazone, there is a regain of interest for metformin action on bone. Borges et al. (2011) recently performed a randomized, parallel group, double-blind, multicenter study comparing the efficacy and safety of Avandamet (AVM; rosiglitazone/metformin) and metformin on BMD after 80 weeks of treatment in drugnaïve type 2 diabetes mellitus patients. A decrease in lumbar spine and total hip BMD were observed in the AVM group while in the metformin group modest increases in lumbar spine and total hip BMD were detected, suggesting that metformin treatment in diabetic patients could have beneficial effects on bone.

\section{Targeting the AMPK pathway for osteoporosis treatment?}

This overview of experimental studies and clinical data clearly indicates that manipulating the AMPK pathway has an impact on skeletal metabolism. Owing to its regulation of the coordination between anabolic and catabolic metabolic pathways, AMPK could represent an attractive therapeutic target for osteoporosis. This is supported by in vitro studies which overall imply that AMPK pathway is beneficial for bone formation while inhibiting bone resorption and by the low bone mass phenotype of mice with germline deletions of AMPK subunits. However, there is no proof yet that AMPK activation can lead to bone formation in vivo. In addition, there are a few conflicting studies describing the deleterious effect on bone of two AMPK activators, AICAR and TZDs. AICAR has been shown to stimulate bone resorption both in vitro and in vivo in mice (Quinn et al. 2010) and TZD treatment in humans leads to an unbalanced remodeling in favor of bone resorption (Grey et al. 2007, Grey 2009, Berberoglu et al. 2010, Lecka-Czernik 2010). The involvement of AMPK activation in this negative impact on skeleton of AICAR and TZDs has not yet been proven. This pinpoints a major problem for all these studies, which is that drugs that are currently used to activate AMPK are non-specific. Furthermore, the widespread AMPK cellular actions make difficult the use of these activators in vivo. New pharmacological AMPK activators are in development for the treatment of diabetes that could be effective in specific target organs and achieved through isoform-specific activation of AMPK. The development of novel AMPK agonists selective for bone could be a similar option considering that AMPK isoforms expression in bone is different from other tissues. The possibility of targeting both osteoporosis and the rapid increase in body weight after the menopause would be very attractive and AMPK, if confirmed to be important for bone formation in vivo, could be a very appealing strategy. Obesity is also a major risk factor for osteoarthritis $(\mathrm{OA})$ and the AMPK pathway could be similarly involved in OA cartilage (Kang et al. 2010). However, despite the rapid progress made during the last decade to clarify the physiological importance of AMPK in diabetes, obesity, insulin resistance, cancer, and cardiovascular diseases, there are still many challenges in understanding the role of AMPK activation in each tissue, the cumulative effects of AMPK activation at the whole-body level, before one can target AMPK therapeutically for disorders of energy metabolism. All the more, the studies investigating the role of AMPK in skeletal physiology are just beginning and much effort is needed to 
clarify the function of AMPK in bone and its contribution to the skeletal effects of antidiabetic drugs. While mutation in the $\gamma 2$ subunit of AMPK causes cardiomyopathy associated with cardiac glycogen storage disorder (Arad et al. 2007), no mutation of AMPK has yet been linked to human bone disorders.

\section{Declaration of interest}

The authors declare that there is no conflict of interest that could be perceived as prejudicing the impartiality of the research reported.

\section{Funding}

This study was supported by the Wellcome Trust.

\section{Acknowledgements}

The authors thank Márta Korbonits for her collaboration.

\section{References}

Ackert-Bicknell CL, Shockley KR, Horton LG, Lecka-Czernik B, Churchill GA \& Rosen CJ 2009 Strain-specific effects of rosiglitazone on bone mass, body composition, and serum insulin-like growth factor-I. Endocrinology 150 1330-1340. (doi:10.1210/en.2008-0936)

Ahdjoudj S, Fromigue O \& Marie PJ 2004 Plasticity and regulation of human bone marrow stromal osteoprogenitor cells: potential implication in the treatment of age-related bone loss. Histology and Histopathology 19 151-157.

Ali AA, Weinstein RS, Stewart SA, Parfitt AM, Manolagas SC \& Jilka RL 2005 Rosiglitazone causes bone loss in mice by suppressing osteoblast differentiation and bone formation. Endocrinology 146 1226-1235. (doi:10. 1210/en.2004-0735)

Andersson U, Filipsson K, Abbott CR, Woods A, Smith K, Bloom SR, Carling D \& Small CJ 2004 AMP-activated protein kinase plays a role in the control of food intake. Journal of Biological Chemistry 279 12005-12008. (doi:10.1074/jbc.C300557200)

Arad M, Seidman CE \& Seidman JG 2007 AMP-activated protein kinase in the heart: role during health and disease. Circulation Research 100 474-488. (doi:10.1161/01.RES.0000258446.23525.37)

Benvenuti S, Cellai I, Luciani P, Deledda C, Baglioni S, Giuliani C, Saccardi R, Mazzanti B, Dal Pozzo S, Mannucci E et al. 2007 Rosiglitazone stimulates adipogenesis and decreases osteoblastogenesis in human mesenchymal stem cells. Journal of Endocrinological Investigation 30 R C26-RC30.

Berberoglu Z, Yazici AC \& Demirag NG 2010 Effects of rosiglitazone on bone mineral density and remodelling parameters in postmenopausal 3 diabetic women: a 2-year follow-up study. Clinical Endocrinology $\mathbf{7 3}$ 305-312. (doi:10.1111/j.1365-2265.2010.03784.x)

Bolster DR, Crozier SJ, Kimball SR \& Jefferson LS 2002 AMP-activated protein kinase suppresses protein synthesis in rat skeletal muscle through down-regulated mammalian target of rapamycin (mTOR) signaling. Journal of Biological Chemistry 277 23977-23980. (doi:10.1074/jbc. C200171200)

Borges JL, Bilezikian JP, Jones-Leone AR, Acusta AP, Ambery PD, Nino AJ, Grosse M, Fitzpatrick LA \& Cobitz AR 2011 A randomized, parallel group, double-blind, multicentre study comparing the efficacy and safety of avandamet (rosiglitazone/metformin) and metformin on long-term glycaemic control and bone mineral density after 80 weeks of treatment in drug-naive type 2 diabetes mellitus patients. Diabetes, Obesity \& Metabolism (In press). (doi:10.1111/j.1463-1326.2011.01461.x)
Burns KA \& Vanden Heuvel JP 2007 Modulation of PPAR activity via phosphorylation. Biochimica et Biophysica Acta 1771 952-960. (doi:10.1016/ j.bbalip.2007.04.018)

Canto C \& Auwerx J 2010 AMP-activated protein kinase and its downstream transcriptional pathways. Cellular and Molecular Life Sciences 67 3407-3423. (doi:10.1007/s00018-010-0454-z)

Cao X \& Chen D 2005 The BMP signaling and in vivo bone formation. Gene 357 1-8. (doi:10.1016/j.gene.2005.06.017)

Carling D 2004 The AMP-activated protein kinase cascade - a unifying system for energy control. Trends in Biochemical Sciences 29 18-24. (doi:10. 1016/j.tibs.2003.11.005)

Carling D, Fryer LG, Woods A, Daniel T, Jarvie SL \& Whitrow H 2003 Bypassing the glucose/fatty acid cycle: AMP-activated protein kinase. Biochemical Society Transactions 31 1157-1160. (doi:10.1042/ BST0311157)

Carling D, Sanders MJ \& Woods A 2008 The regulation of AMP-activated protein kinase by upstream kinases. International Journal of Obesity 32 (Suppl 4) S55-S59. (doi:10.1038/ijo.2008.124)

Cho SW, Yang JY, Her SJ, Choi HJ, Jung JY, Sun HJ, An JH, Cho HY, Kim SW, Park KS et al. 2011 Osteoblast-targeted overexpression of PPARgamma inhibited bone mass gain in male mice and accelerated ovariectomy-induced bone loss in female mice. Journal of Bone and Mineral Research 26 1939-1952. (doi:10.1002/jbmr.366)

Cornish J, Callon KE \& Reid IR 1996 Insulin increases histomorphometric indices of bone formation In vivo. Calcified Tissue International 59 492-495. (doi:10.1007/s002239900163)

Cornish J, Callon KE, Bava U, Lin C, Naot D, Hill BL, Grey AB, Broom N, Myers DE, Nicholson GC et al. 2002 Leptin directly regulates bone cell function in vitro and reduces bone fragility in vivo. Journal of Endocrinology 175 405-415. (doi:10.1677/joe.0.1750405)

Cortizo AM, Sedlinsky C, McCarthy AD, Blanco A \& Schurman L 2006 Osteogenic actions of the anti-diabetic drug metformin on osteoblasts in culture. European Journal of Pharmacology 536 38-46. (doi:10.1016/j.ejphar. 2006.02.030)

Corton JM, Gillespie JG, Hawley SA \& Hardie DG 1995 5-Aminoimidazole4-carboxamide ribonucleoside. A specific method for activating AMPactivated protein kinase in intact cells? European Journal of Biochemistry 229 558-565. (doi:10.1111/j.1432-1033.1995.tb20498.x)

Daval M, Diot-Dupuy F, Bazin R, Hainault I, Viollet B, Vaulont S, Hajduch E, Ferre P \& Foufelle F 2005 Anti-lipolytic action of AMP-activated protein kinase in rodent adipocytes. Journal of Biological Chemistry 280 25250-25257. (doi:10.1074/jbc.M414222200)

De Laet C, Kanis JA, Oden A, Johanson H, Johnell O, Delmas P, Eisman JA, Kroger H, Fujiwara S, Garnero P et al. 2005 Body mass index as a predictor of fracture risk: a meta-analysis. Osteoporosis International 16 1330-1338. (doi:10.1007/s00198-005-1863-y)

Delany AM, Dong Y \& Canalis E 1994 Mechanisms of glucocorticoid action in bone cells. Journal of Cellular Biochemistry 56 295-302. (doi:10.1002/jcb. 240560304)

Ducy P 2000 Cbfa1: a molecular switch in osteoblast biology. Developmental Dynamics 219 461-471. (doi:10.1002/1097-0177(2000)9999:9999<::AID -DVDY1074 > 3.0.CO;2-C)

Ducy P, Amling M, Takeda S, Priemel M, Schilling AF, Beil FT, Shen J, Vinson C, Rueger JM \& Karsenty G 2000 Leptin inhibits bone formation through a hypothalamic relay: a central control of bone mass. Cell $\mathbf{1 0 0}$ 197-207. (doi:10.1016/S0092-8674(00)81558-5)

Dunford JE 2010 Molecular targets of the nitrogen containing bisphosphonates: the molecular pharmacology of prenyl synthase inhibition. Current Pharmaceutical Design 16 2961-2969. (doi:10.2174/ 138161210793563617)

Dytfeld J, Ignaszak-Szczepaniak M, Gowin E, Michalak M \& Horst-Sikorska W 2011 Influence of lean and fat mass on bone mineral density (BMD) in postmenopausal women with osteoporosis. Archives of Gerontology and Geriatrics 53 e237-e242. (doi:10.1016/j.archger.2011.01.002)

Dzamko NL \& Steinberg GR 2009 AMPK-dependent, hormonal regulation of whole-body energy metabolism. Acta Physiologica 196 115-127. (doi:10. $1111 /$ j.1748-1716.2009.01969.x) 
Edwards BJ, Bunta AD, Simonelli C, Bolander M \& Fitzpatrick LA 2007 Prior fractures are common in patients with subsequent hip fractures. Clinical Orthopaedics and Related Research 461 226-230. (doi:10.1097/BLO. Ob013e3180534269)

Elefteriou F, Ahn JD, Takeda S, Starbuck M, Yang X, Liu X, Kondo H, Richards WG, Bannon TW, Noda M et al. 2005 Leptin regulation of bone resorption by the sympathetic nervous system and CART. Nature $\mathbf{4 3 4}$ 514-520. (doi:10.1038/nature03398)

Ewart MA \& Kennedy S 2011 AMPK and vasculoprotection. Pharmacology and Therapeutics 131 242-253. (doi:10.1016/j.pharmthera.2010.11.002)

Ferron M, Wei J, Yoshizawa T, Del Fattore A, DePinho RA, Teti A, Ducy P \& Karsenty G 2010 Insulin signaling in osteoblasts integrates bone remodeling and energy metabolism. Cell 142 296-308. (doi:10. 1016/j.cell.2010.06.003)

Fogarty S \& Hardie DG 2010 Development of protein kinase activators: AMPK as a target in metabolic disorders and cancer. Biochimica et Biophysica Acta 1804 581-591. (doi:10.1016/j.bbapap.2009.09.012)

Foretz M, Hebrard S, Leclerc J, Zarrinpashneh E, Soty M, Mithieux G, Sakamoto K, Andreelli F \& Viollet B 2010 Metformin inhibits hepatic gluconeogenesis in mice independently of the LKB1/AMPK pathway via a decrease in hepatic energy state. Journal of Clinical Investigation $\mathbf{1 2 0}$ 2355-2369. (doi:10.1172/JCI40671)

Fryer LG, Parbu-Patel A \& Carling D 2002 The Anti-diabetic drugs rosiglitazone and metformin stimulate AMP-activated protein kinase through distinct signaling pathways. Journal of Biological Chemistry 277 25226-25232. (doi:10.1074/jbc.M202489200)

Fulzele K, Riddle RC, DiGirolamo DJ, Cao X, Wan C, Chen D, Faugere MC, Aja S, Hussain MA, Bruning JC et al. 2010 Insulin receptor signaling in osteoblasts regulates postnatal bone acquisition and body composition. Cell 142 309-319. (doi:10.1016/j.cell.2010.06.002)

Gao S, Kinzig KP, Aja S, Scott KA, Keung W, Kelly S, Strynadka K, Chohnan S, Smith WW, Tamashiro KL et al. 2007 Leptin activates hypothalamic acetyl-CoA carboxylase to inhibit food intake. PNAS 104 17358-17363. (doi:10.1073/pnas.0708385104)

Gao Y, Li Y, Xue J, Jia Y \& Hu J 2010 Effect of the anti-diabetic drug metformin on bone mass in ovariectomized rats. European Journal of Pharmacology 635 231-236. (doi:10.1016/j.ejphar.2010.02.051)

Gimble JM, Robinson CE, Wu X, Kelly KA, Rodriguez BR, Kliewer SA, Lehmann JM \& Morris DC 1996 Peroxisome proliferator-activated receptor-gamma activation by thiazolidinediones induces adipogenesis in bone marrow stromal cells. Molecular Pharmacology 50 1087-1094.

Greer EL, Oskoui PR, Banko MR, Maniar JM, Gygi MP, Gygi SP \& Brunet A 2007 The energy sensor AMP-activated protein kinase directly regulates the mammalian FOXO3 transcription factor. Journal of Biological Chemistry 282 30107-30119. (doi:10.1074/jbc.M705325200)

Grey A 2008 Skeletal consequences of thiazolidinedione therapy. Osteoporosis International 19 129-137. (doi:10.1007/s00198-007-0477-y)

Grey A 2009 Thiazolidinedione-induced skeletal fragility - mechanisms and implications. Diabetes, Obesity and Metabolism 11 275-284. (doi:10.1111/j. 1463-1326.2008.00931.x)

Grey A, Bolland M, Gamble G, Wattie D, Horne A, Davidson J \& Reid IR 2007 The peroxisome proliferator-activated receptor-gamma agonist rosiglitazone decreases bone formation and bone mineral density in healthy postmenopausal women: a randomized, controlled trial. Journal of Clinical Endocrinology and Metabolism 92 1305-1310. (doi:10.1210/jc.2006-2646)

Hardie DG 2003 Minireview: the AMP-activated protein kinase cascade: the key sensor of cellular energy status. Endocrinology 144 5179-5183. (doi:10. 1210/en.2003-0982)

Hardie DG 2004 AMP-activated protein kinase: a key system mediating metabolic responses to exercise. Medicine and Science in Sports and Exercise 36 28-34. (doi:10.1249/01.MSS.0000106171.38299.64)

Hardie DG 2007 AMP-activated/SNF1 protein kinases: conserved guardians of cellular energy. Nature Reviews. Molecular Cell Biology 8774-785. (doi:10. 1038/nrm2249)

Hardie DG 2008 AMPK: a key regulator of energy balance in the single cell and the whole organism. International Journal of Obesity 32 (Suppl 4) S7-12. (doi:10.1038/ijo.2008.116)
Hardie DG 2011 Sensing of energy and nutrients by AMP-activated protein kinase. American Journal of Clinical Nutrition 93 891S-896S. (doi:10.3945/ ajcn.110.001925)

Hardie DG \& Pan DA 2002 Regulation of fatty acid synthesis and oxidation by the AMP-activated protein kinase. Biochemical Society Transactions 30 1064-1070. (doi:10.1042/BST0301064)

Hardie DG \& Sakamoto K 2006 AMPK: a key sensor of fuel and energy status in skeletal muscle. Physiology 21 48-60. (doi:10.1152/physiol.00044.2005)

Hardie DG, Carling D \& Carlson M 1998 The AMP-activated/SNF1 protein kinase subfamily: metabolic sensors of the eukaryotic cell? Annual Review of Biochemistry 67 821-855. (doi:10.1146/annurev.biochem.67.1.821)

Hardie DG, Hawley SA \& Scott JW 2006 AMP-activated protein kinase development of the energy sensor concept. Journal of Physiology 574 7-15. (doi:10.1113/jphysiol.2006.108944)

Harvey N, Dennison E \& Cooper C 2010 Osteoporosis: impact on health and economics. Nature Reviews. Rheumatology 699-105. (doi:10.1038/ nrrheum.2009.260)

Hawley SA, Pan DA, Mustard KJ, Ross L, Bain J, Edelman AM, Frenguelli BG \& Hardie DG 2005 Calmodulin-dependent protein kinase kinase-beta is an alternative upstream kinase for AMP-activated protein kinase. Cell Metabolism 2 9-19. (doi:10.1016/j.cmet.2005.05.009)

Hawley SA, Ross FA, Chevtzoff C, Green KA, Evans A, Fogarty S, Towler MC, Brown LJ, Ogunbayo OA, Evans AM et al. 2010 Use of cells expressing gamma subunit variants to identify diverse mechanisms of AMPK activation. Cell Metabolism 11 554-565. (doi:10.1016/j.cmet.2010. 04.001)

Holmes BF, Kurth-Kraczek EJ \& Winder WW 1999 Chronic activation of $5^{\prime}$-AMP-activated protein kinase increases GLUT-4, hexokinase, and glycogen in muscle. Journal of Applied Physiology 87 1990-1995.

Horiuchi N \& Maeda T 2006 Statins and bone metabolism. Oral Disease 12 85-101. (doi:10.1111/j.1601-0825.2005.01172.x)

Hou CH, Tan TW \& Tang CH 2008 AMP-activated protein kinase is involved in COX-2 expression in response to ultrasound in cultured osteoblasts. Cellular Signalling 20 978-988. (doi:10.1016/j.cellsig.2008.01.013)

Hsu YH, Venners SA, Terwedow HA, Feng Y, Niu T, Li Z, Laird N, Brain JD, Cummings SR, Bouxsein ML et al. 2006 Relation of body composition, fat mass, and serum lipids to osteoporotic fractures and bone mineral density in Chinese men and women. American Journal of Clinical Nutrition 83 146-154.

Huypens P, Moens K, Heimberg H, Ling Z, Pipeleers D \& Van de Casteele M 2005 Adiponectin-mediated stimulation of AMP-activated protein kinase (AMPK) in pancreatic beta cells. Life Sciences 77 1273-1282. (doi:10.1016/ j.lfs.2005.03.008)

Jager S, Handschin C, St-Pierre J \& Spiegelman BM 2007 AMP-activated protein kinase (AMPK) action in skeletal muscle via direct phosphorylation of PGC-1alpha. PNAS 104 12017-12022. (doi:10.1073/pnas. 0705070104)

Jang WG, Kim EJ, Bae IH, Lee KN, Kim YD, Kim DK, Kim SH, Lee CH, Franceschi RT, Choi HS et al. 2011 Metformin induces osteoblast differentiation via orphan nuclear receptor SHP-mediated transactivation of Runx2. Bone 48 885-893. (doi:10.1016/j.bone.2010.12.003)

Jones RG, Plas DR, Kubek S, Buzzai M, Mu J, Xu Y, Birnbaum MJ \& Thompson CB 2005 AMP-activated protein kinase induces a p53dependent metabolic checkpoint. Molecular Cell 18 283-293. (doi:10.1016/ j.molcel.2005.03.027)

Jorgensen SB, Viollet B, Andreelli F, Frosig C, Birk JB, Schjerling P, Vaulont S, Richter EA \& Wojtaszewski JF 2004 Knockout of the alpha2 but not alpha1 $5^{\prime}$-AMP-activated protein kinase isoform abolishes 5-aminoimidazole-4carboxamide-1-beta-4-ribofuranosidebut not contraction-induced glucose uptake in skeletal muscle. Journal of Biological Chemistry 279 1070-1079. (doi:10.1074/jbc.M306205200)

Kahn BB, Alquier T, Carling D \& Hardie DG 2005 AMP-activated protein kinase: ancient energy gauge provides clues to modern understanding of metabolism. Cell Metabolism 1 15-25. (doi:10.1016/j.cmet.2004.12.003)

Kahn SE, Zinman B, Lachin JM, Haffner SM, Herman WH, Holman RR, Kravitz BG, Yu D, Heise MA, Aftring RP et al. 2008 Rosiglitazoneassociated fractures in type 2 diabetes: an analysis from a Diabetes Outcome Progression Trial (ADOPT). Diabetes Care 31 845-851. (doi:10.2337/ dc07-2270) 
Kanazawa I, Yamaguchi T, Yano S, Yamauchi M, Yamamoto M \& Sugimoto T 2007 Adiponectin and AMP kinase activator stimulate proliferation, differentiation, and mineralization of osteoblastic MC3T3-E1 cells. BMC Cell Biology 8 51. (doi:10.1186/1471-2121-8-51)

Kanazawa I, Yamaguchi T, Yano S, Yamauchi M \& Sugimoto T 2008 Metformin enhances the differentiation and mineralization of osteoblastic MC3T3-E1 cells via AMP kinase activation as well as eNOS and BMP-2 expression. Biochemical and Biophysical Research Communications 375 414-419. (doi:10.1016/j.bbrc.2008.08.034)

Kanazawa I, Yamaguchi T, Yano S, Hayashi K, Yamauchi M \& Sugimoto T $2009 a$ Inhibition of the mevalonate pathway rescues the dexamethasoneinduced suppression of the mineralization in osteoblasts via enhancing bone morphogenetic protein-2 signal. Hormone and Metabolic Research 41 612-616. (doi:10.1055/s-0029-1220684)

Kanazawa I, Yamaguchi T, Yano S, Yamauchi M \& Sugimoto T 2009b Activation of AMP kinase and inhibition of Rho kinase induce the mineralization of osteoblastic MC3T3-E1 cells through endothelial NOS and BMP-2 expression. American Journal of Physiology. Endocrinology and Metabolism 296 E139-E146. (doi:10.1152/ajpendo.90677.2008)

Kang S, Bennett CN, Gerin I, Rapp LA, Hankenson KD \& Macdougald OA $2007 \mathrm{Wnt}$ signaling stimulates osteoblastogenesis of mesenchymal precursors by suppressing CCAAT/enhancer-binding protein alpha and peroxisome proliferator-activated receptor gamma. Journal of Biological Chemistry 282 14515-14524. (doi:10.1074/jbc.M700030200)

Kang EH, Lee YJ, Kim TK, Chang CB, Chung JH, Shin K, Lee EY, Lee EB \& Song YW 2010 Adiponectin is a potential catabolic mediator in osteoarthritis cartilage. Arthritis Research \& Therapy 12 R231. (doi:10. 1186/ar3218)

Kasai T, Bandow K, Suzuki H, Chiba N, Kakimoto K, Ohnishi T, Kawamoto S, Nagaoka E \& Matsuguchi T 2009 Osteoblast differentiation is functionally associated with decreased AMP kinase activity. Journal of Cellular Physiology 221 740-749. (doi:10.1002/jcp.21917)

Kazgan N, Williams T, Forsberg LJ \& Brenman JE 2010 Identification of a nuclear export signal in the catalytic subunit of AMP-activated protein kinase. Molecular Biology of the Cell 21 3433-3442. (doi:10.1091/mbc. E10-04-0347)

Kim JM, Jeong D, Kang HK, Jung SY, Kang SS \& Min BM 2007 Osteoclast precursors display dynamic metabolic shifts toward accelerated glucose metabolism at an early stage of RANKL-stimulated osteoclast differentiation. Cellular Physiology and Biochemistry 20 935-946. (doi:10.1159/ 000110454)

Kim JE, Ahn MW, Baek SH, Lee IK, Kim YW, Kim JY, Dan JM \& Park SY 2008 AMPK activator AICAR, inhibits palmitate-induced apoptosis in osteoblast. Bone 43 394-404. (doi:10.1016/j.bone.2008.03.021)

Kola B, Hubina E, Tucci SA, Kirkham TC, Garcia EA, Mitchell SE, Williams LM, Hawley SA, Hardie DG, Grossman AB et al. 2005 Cannabinoids and ghrelin have both central and peripheral metabolic and cardiac effects via AMP-activated protein kinase. Journal of Biological Chemistry 280 25196-25201. (doi:10.1074/jbc.C500175200)

Kola B, Boscaro M, Rutter GA, Grossman AB \& Korbonits M 2006 Expanding role of AMPK in endocrinology. Trends in Endocrinology and Metabolism 17 205-215. (doi:10.1016/j.tem.2006.05.006)

Komarova SV, Ataullakhanov FI \& Globus RK 2000 Bioenergetics and mitochondrial transmembrane potential during differentiation of cultured osteoblasts. American Journal of Physiology. Cell Physiology 279 C1220-C1229.

Korbonits M, Goldstone AP, Gueorguiev M \& Grossman AB 2004 Ghrelin - a hormone with multiple functions. Frontiers in Neuroendocrinology 25 27-68. (doi:10.1016/j.yfrne.2004.03.002)

Lage R, Dieguez C, Vidal-Puig A \& Lopez M 2008 AMPK: a metabolic gauge regulating whole-body energy homeostasis. Trends in Molecular Medicine 14 539-549. (doi:10.1016/j.molmed.2008.09.007)

Lazarenko OP, Rzonca SO, Hogue WR, Swain FL, Suva LJ \& Lecka-Czernik B 2007 Rosiglitazone induces decreases in bone mass and strength that are reminiscent of aged bone. Endocrinology 148 2669-2680. (doi:10.1210/en. 2006-1587)

LeBrasseur NK, Kelly M, Tsao TS, Farmer SR, Saha AK, Ruderman NB \& Tomas E 2006 Thiazolidinediones can rapidly activate AMP-activated protein kinase in mammalian tissues. American Journal of Physiology. Endocrinology and Metabolism 291 E175-E181. (doi:10.1152/ajpendo. 00453.2005)

Lecka-Czernik B 2010 Bone loss in diabetes: use of antidiabetic thiazolidinediones and secondary osteoporosis. Current Osteoporosis Reports 8 178-184. (doi:10.1007/s11914-010-0027-y)

Lecka-Czernik B, Gubrij I, Moerman EJ, Kajkenova O, Lipschitz DA, Manolagas SC \& Jilka RL 1999 Inhibition of Osf2/Cbfa1 expression and terminal osteoblast differentiation by PPARgamma2. Journal of Cellular Biochemistry 74 357-371. (doi:10.1002/(SICI)1097-4644(19990901)74:3 $<357::$ AID-JCB5 > 3.0.CO;2-7)

Lee WH \& Kim SG 2010 AMPK-dependent metabolic regulation by PPAR agonists. PPAR Research 2010. (doi:10.1155/2010/549101)

Lee Y, Naseem RH, Duplomb L, Park BH, Garry DJ, Richardson JA, Schaffer JE \& Unger RH 2004 Hyperleptinemia prevents lipotoxic cardiomyopathy in acyl CoA synthase transgenic mice. PNAS 101 13624-13629. (doi:10. 1073/pnas.0405499101)

Lee K, Li B, Xi X, Suh Y \& Martin RJ 2005 Role of neuronal energy status in the regulation of adenosine $5^{\prime}$-monophosphate-activated protein kinase, orexigenic neuropeptides expression, and feeding behavior. Endocrinology 146 3-10. (doi:10.1210/en.2004-0968)

Lee NK, Sowa H, Hinoi E, Ferron M, Ahn JD, Confavreux C, Dacquin R, Mee PJ, McKee MD, Jung DY et al. 2007 Endocrine regulation of energy metabolism by the skeleton. Cell 130 456-469. (doi:10.1016/j.cell.2007. 05.047)

Lee YS, Kim YS, Lee SY, Kim GH, Kim BJ, Lee SH, Lee KU, Kim GS, Kim SW \& Koh JM 2010 AMP kinase acts as a negative regulator of RANKL in the differentiation of osteoclasts. Bone 47 926-937. (doi:10.1016/j.bone. 2010.08.001)

Leff T 2003 AMP-activated protein kinase regulates gene expression by direct phosphorylation of nuclear proteins. Biochemical Society Transactions $\mathbf{3 1}$ 224-227. (doi:10.1042/BST0310224)

Levine YC, Li GK \& Michel T 2007 Agonist-modulated regulation of AMPactivated protein kinase (AMPK) in endothelial cells. Evidence for an $\mathrm{AMPK} \rightarrow \mathrm{Rac} 1 \rightarrow \mathrm{Akt} \rightarrow$ endothelial nitric-oxide synthase pathway. Journal of Biological Chemistry 282 20351-20364. (doi:10.1074/jbc. M702182200)

Li M, Pan LC, Simmons HA, Li Y, Healy DR, Robinson BS, Ke HZ \& Brown TA 2006 Surface-specific effects of a PPARgamma agonist, darglitazone, on bone in mice. Bone 39 796-806. (doi:10.1016/j.bone. 2006.04.008)

Lim CT, Kola B \& Korbonits M 2010 AMPK as a mediator of hormonal signalling. Journal of Molecular Endocrinology 44 87-97. (doi:10.1677/JME09-0063)

Lopez JM 2008 Is ZMP the toxic metabolite in Lesch-Nyhan disease? Medical Hypotheses 71 657-663. (doi:10.1016/j.mehy.2008.06.033)

Lopez M, Lelliott CJ \& Vidal-Puig A 2007 Hypothalamic fatty acid metabolism: a housekeeping pathway that regulates food intake. Bioessays 29 248-261. (doi:10.1002/bies.20539)

Lopez M, Lage R, Saha AK, Perez-Tilve D, Vazquez MJ, Varela L, SangiaoAlvarellos S, Tovar S, Raghay K, Rodriguez-Cuenca S et al. 2008 Hypothalamic fatty acid metabolism mediates the orexigenic action of ghrelin. Cell Metabolism 7 389-399. (doi:10.1016/j.cmet.2008.03.006)

Maccarinelli G, Sibilia V, Torsello A, Raimondo F, Pitto M, Giustina A, Netti C \& Cocchi D 2005 Ghrelin regulates proliferation and differentiation of osteoblastic cells. Journal of Endocrinology 184 249-256. (doi:10.1677/joe.1. 05837)

Maeda N, Takahashi M, Funahashi T, Kihara S, Nishizawa H, Kishida K, Nagaretani H, Matsuda M, Komuro R, Ouchi N et al. 2001 PPARgamma ligands increase expression and plasma concentrations of adiponectin, an adipose-derived protein. Diabetes 50 2094-2099. (doi:10.2337/diabetes.50. 9.2094)

Mai Q, Zhang Z, Xu S, Lu M, Zhou R, Zhao L, Jia C, Wen Z, Jin D \& Bai X 2011 Metformin stimulates osteoprotegerin and reduces RANKL expression in osteoblasts and ovariectomized rats. Journal of Cellular Biochemistry 112 2902-2909. (doi:10.1002/jcb.23206) 
Mantovani J \& Roy R 2011 Re-evaluating the general(ized) roles of AMPK in cellular metabolism. FEBS Letters 585 967-972. (doi:10.1016/j.febslet. 2010.12.015)

Mayer A, Denanglaire S, Viollet B, Leo O \& Andris F 2008 AMP-activated protein kinase regulates lymphocyte responses to metabolic stress but is largely dispensable for immune cell development and function. European Journal of Immunology 38 948-956. (doi:10.1002/eji.200738045)

McBride A \& Hardie DG 2009 AMP-activated protein kinase - a sensor of glycogen as well as AMP and ATP? Acta Physiologica 196 99-113. (doi:10. $1111 / \mathrm{j} .1748-1716.2009 .01975 . \mathrm{x})$

McGee SL \& Hargreaves M 2008 AMPK and transcriptional regulation. Frontiers in Bioscience 13 3022-3033. (doi:10.2741/2907)

Minokoshi Y, Kim YB, Peroni OD, Fryer LG, Muller C, Carling D \& Kahn BB 2002 Leptin stimulates fatty-acid oxidation by activating AMP-activated protein kinase. Nature 415 339-343. (doi:10.1038/415339a)

Minokoshi Y, Alquier T, Furukawa N, Kim YB, Lee A, Xue B, Mu J, Foufelle F, Ferre P, Birnbaum MJ et al. 2004 AMP-kinase regulates food intake by responding to hormonal and nutrient signals in the hypothalamus. Nature 428 569-574. (doi:10.1038/nature02440)

Molinuevo MS, Schurman L, McCarthy AD, Cortizo AM, Tolosa MJ, Gangoiti MV, Arnol V \& Sedlinsky C 2010 Effect of metformin on bone marrow progenitor cell differentiation: in vivo and in vitro studies. Journal of Bone and Mineral Research 25 211-221. (doi:10.1359/jbmr. 090732)

Mooney MH, Fogarty S, Stevenson C, Gallagher AM, Palit P, Hawley SA, Hardie DG, Coxon GD, Waigh RD, Tate RJ et al. 2008 Mechanisms underlying the metabolic actions of galegine that contribute to weight loss in mice. British Journal of Pharmacology 153 1669-1677. (doi:10.1038/bjp. 2008.37)

Moreno D, Knecht E, Viollet B \& Sanz P 2008 A769662, a novel activator of AMP-activated protein kinase, inhibits non-proteolytic components of the $26 \mathrm{~S}$ proteasome by an AMPK-independent mechanism. FEBS Letters $\mathbf{5 8 2}$ 2650-2654. (doi:10.1016/j.febslet.2008.06.044)

Motoshima H, Goldstein BJ, Igata M \& Araki E 2006 AMPK and cell proliferation - AMPK as a therapeutic target for atherosclerosis and cancer Journal of Physiology 574 63-71. (doi:10.1113/jphysiol.2006.108324)

Mukherjee A \& Rotwein P 2009 Akt promotes BMP2-mediated osteoblast differentiation and bone development. Journal of Cell Science 122 716-726. (doi:10.1242/jcs.042770)

Oakhill JS, Scott JW \& Kemp BE 2009 Structure and function of AMPactivated protein kinase. Acta Physiologica 196 3-14. (doi:10.1111/j.17481716.2009.01977.x)

Oliaro-Bosso S, Calcio Gaudino E, Mantegna S, Giraudo E, Meda C, Viola F \& Cravotto G 2009 Regulation of HMGCoA reductase activity by policosanol and octacosadienol, a new synthetic analogue of octacosanol. Lipids 44 907-916. (doi:10.1007/s11745-009-3338-y)

Oshima K, Nampei A, Matsuda M, Iwaki M, Fukuhara A, Hashimoto J, Yoshikawa H \& Shimomura I 2005 Adiponectin increases bone mass by suppressing osteoclast and activating osteoblast. Biochemical and Biophysical Research Communications 331 520-526. (doi:10.1016/j.bbrc.2005.03.210)

Pang T, Zhang ZS, Gu M, Qiu BY, Yu LF, Cao PR, Shao W, Su MB, Li JY, Nan FJ et al. 2008 Small molecule antagonizes autoinhibition and activates AMP-activated protein kinase in cells. Journal of Biological Chemistry $\mathbf{2 8 3}$ 16051-16060. (doi:10.1074/jbc.M710114200)

de Paula FJ, Horowitz MC \& Rosen CJ 2010 Novel insights into the relationship between diabetes and osteoporosis. Diabetes/Metabolism Research and Reviews 26 622-630. (doi:10.1002/dmrr.1135)

Pei L \& Tontonoz P 2004 Fat's loss is bone's gain. Journal of Clinical Investigation 113 805-806.

Peng XD, Xu PZ, Chen ML, Hahn-Windgassen A, Skeen J, Jacobs J, Sundararajan D, Chen WS, Crawford SE, Coleman KG et al. 2003 Dwarfism, impaired skin development, skeletal muscle atrophy, delayed bone development, and impeded adipogenesis in mice lacking Akt1 and Akt2. Genes and Development 17 1352-1365. (doi:10.1101/gad.1089403)

Premaor MO, Ensrud K, Lui L, Parker RA, Cauley J, Hillier TA, Cummings S \& Compston JE 2011 Risk factors for nonvertebral fracture in obese older women. Journal of Clinical Endocrinology 96 2414-2421. (doi:10.1210/jc. 2011-0076)
Qi J, Gong J, Zhao T, Zhao J, Lam P, Ye J, Li JZ, Wu J, Zhou HM \& Li P 2008 Downregulation of AMP-activated protein kinase by Cidea-mediated ubiquitination and degradation in brown adipose tissue. EMBO Journal 27 1537-1548. (doi:10.1038/emboj.2008.92)

Quinn JM, Tam S, Sims NA, Saleh H, McGregor NE, Poulton IJ, Scott JW, Gillespie MT, Kemp BE \& van Denderen BJ 2010 Germline deletion of AMP-activated protein kinase beta subunits reduces bone mass without altering osteoclast differentiation or function. FASEB Journal 24 275-285. (doi:10.1096/fj.09-137158)

Reid IR 2008 Relationships between fat and bone. Osteoporosis International 19 595-606. (doi:10.1007/s00198-007-0492-z)

Reid IR, Ames R, Evans MC, Sharpe S, Gamble G, France JT, Lim TM \& Cundy TF 1992 Determinants of total body and regional bone mineral density in normal postmenopausal women - a key role for fat mass. Journal of Clinical Endocrinology and Metabolism 75 45-51. (doi:10.1210/ jc.75.1.45)

Reihill JA, Ewart MA, Hardie DG \& Salt IP 2007 AMP-activated protein kinase mediates VEGF-stimulated endothelial NO production. Biochemical and Biophysical Research Communications 354 1084-1088. (doi:10.1016/ j.bbrc.2007.01.110)

Rogers MJ, Crockett JC, Coxon FP \& Monkkonen J 2010 Biochemical and molecular mechanisms of action of bisphosphonates. Bone 49 34-41. (doi:10.1016/j.bone.2010.11.008)

Rosen CJ \& Bouxsein ML 2006 Mechanisms of disease: is osteoporosis the obesity of bone? Nature Clinical Practice. Rheumatology 2 35-43. (doi:10. 1038/ncprheum0070)

Rossoni LV, Wareing M, Wenceslau C, Al-Abri M, Cobb C \& Austin CE 2011 Acute simvastatin increases endothelial nitric oxide synthase phosphorylation via AMP-activated protein kinase and reduces contractility of isolated rat mesenteric resistance arteries. Clinical Science 121 449-458. (doi:10.1042/CS20110259)

Russell RG, Watts NB, Ebetino FH \& Rogers MJ 2008 Mechanisms of action of bisphosphonates: similarities and differences and their potential influence on clinical efficacy. Osteoporosis International 19 733-759. (doi:10.1007/ s00198-007-0540-8)

Rutter GA, Da Silva Xavier G \& Leclerc I 2003 Roles of 5'-AMP-activated protein kinase (AMPK) in mammalian glucose homoeostasis. Biochemical Journal 375 1-16. (doi:10.1042/BJ20030048)

Rzonca SO, Suva LJ, Gaddy D, Montague DC \& Lecka-Czernik B 2004 Bone is a target for the antidiabetic compound rosiglitazone. Endocrinology $\mathbf{1 4 5}$ 401-406. (doi:10.1210/en.2003-0746)

Sanders MJ, Grondin PO, Hegarty BD, Snowden MA \& Carling D 2007 Investigating the mechanism for AMP activation of the AMP-activated protein kinase cascade. Biochemical Journal 403 139-148. (doi:10.1042/ BJ20061520)

Scott JW, van Denderen BJ, Jorgensen SB, Honeyman JE, Steinberg GR, Oakhill JS, Iseli TJ, Koay A, Gooley PR, Stapleton D et al. 2008 Thienopyridone drugs are selective activators of AMP-activated protein kinase beta1-containing complexes. Chemistry \& Biology 15 1220-1230. (doi:10.1016/j.chembiol.2008.10.005)

Scott JW, Oakhill JS \& van Denderen BJ 2009 AMPK/SNF1 structure: a menage a trois of energy-sensing. Frontiers in Bioscience 14 596-610. (doi:10. 2741/3266)

Shah M, Kola B, Bataveljic A, Arnett TR, Viollet B, Saxon L, Korbonits M \& Chenu C 2010 AMP-activated protein kinase (AMPK) activation regulates in vitro bone formation and bone mass. Bone 47 309-319. (doi:10.1016/ j.bone.2010.04.596)

Shah M, Viollet B, Korbonits M \& Chenu C 2011 Deletion of Amp-activated protein kinase (AMPK)-alpha 1 catalytic subunit in mice impairs the in vivo response of bones to hormonal challenges. Bone $\mathbf{4 8}$ S96-S96. (doi:10.1016/ j.bone.2011.03.139)

Shen Z, Liang X, Rogers CQ, Rideout D \& You M 2010 Involvement of adiponectin-SIRT1-AMPK signaling in the protective action of rosiglitazone against alcoholic fatty liver in mice. American Journal of Physiology. Gastrointestinal and Liver Physiology 298 G364-G374. (doi:10.1152/ajpgi. 00456.2009)

Shibata R, Sato K, Pimentel DR, Takemura Y, Kihara S, Ohashi K, Funahashi T, Ouchi N \& Walsh K 2005 Adiponectin protects against 
myocardial ischemia-reperfusion injury through AMPK- and COX2-dependent mechanisms. Nature Medicine 11 1096-1103. (doi:10.1038/ nm1295)

Soroceanu MA, Miao D, Bai XY, Su H, Goltzman D \& Karaplis AC 2004 Rosiglitazone impacts negatively on bone by promoting osteoblast/osteocyte apoptosis. Journal of Endocrinology 183 203-216. (doi:10.1677/joe.1. 05723)

Sottile V, Seuwen K \& Kneissel M 2004 Enhanced marrow adipogenesis and bone resorption in estrogen-deprived rats treated with the PPARgamma agonist BRL49653 (rosiglitazone). Calcified Tissue International 75 329-337. (doi:10.1007/s00223-004-0224-8)

Steinberg GR \& Jorgensen SB 2007 The AMP-activated protein kinase: role in regulation of skeletal muscle metabolism and insulin sensitivity. Mini Reviews in Medicinal Chemistry 7 519-526. (doi:10.2174/1389557077806 19662)

Steinberg GR \& Kemp BE 2009 AMPK in health and disease. Physiological Reviews 89 1025-1078. (doi:10.1152/physrev.00011.2008)

Steinberg GR, Watt MJ \& Febbraio MA 2009 Cytokine regulation of AMPK signalling. Frontiers in Bioscience 14 1902-1916. (doi:10.2741/ 3350)

Sugatani T \& Hruska KA 2005 Akt1/Akt2 and mammalian target of rapamycin/Bim play critical roles in osteoclast differentiation and survival, respectively, whereas Akt is dispensable for cell survival in isolated osteoclast precursors. Journal of Biological Chemistry 280 3583-3589. (doi:10.1074/jbc. M410480200)

Takada I, Suzawa M, Matsumoto K \& Kato S 2007 Suppression of PPAR transactivation switches cell fate of bone marrow stem cells from adipocytes into osteoblasts. Annals of the New York Academy of Sciences 1116 182-195. (doi:10.1196/annals.1402.034)

Takeda S, Elefteriou F, Levasseur R, Liu X, Zhao L, Parker KL, Armstrong D, Ducy P \& Karsenty G 2002 Leptin regulates bone formation via the sympathetic nervous system. Cell 111 305-317. (doi:10.1016/S00928674(02)01049-8)

Tamas P, Hawley SA, Clarke RG, Mustard KJ, Green K, Hardie DG \& Cantrell DA 2006 Regulation of the energy sensor AMP-activated protein kinase by antigen receptor and $\mathrm{Ca}^{2+}$ in T lymphocytes. Journal of Experimental Medicine 203 1665-1670. (doi:10.1084/jem.20052469)

van Thuijl H, Kola B \& Korbonits M 2008 Appetite and metabolic effects of ghrelin and cannabinoids: involvement of AMP-activated protein kinase. Vitamins and Hormones 77 121-148.

Tomaselli S, Meli M, Plescia J, Zetta L, Altieri DC, Colombo G \& Ragona L 2010 Combined in silico and experimental approach for drug design: the binding mode of peptidic and non-peptidic inhibitors to hsp $90 \mathrm{~N}$-terminal domain. Chemical Biology \& Drug Design 76 382-391. (doi:10.1111/j.17470285.2010.01015.x)

Tsou P, Zheng B, Hsu CH, Sasaki AT \& Cantley LCA 2011 A fluorescent reporter of AMPK activity and cellular energy stress. Cell Metabolism $\mathbf{1 3}$ 476-486. (doi:10.1016/j.cmet.2011.03.006)

Turner N, Li JY, Gosby A, To SW, Cheng Z, Miyoshi H, Taketo MM, Cooney GJ, Kraegen EW, James DE et al. 2008 Berberine and its more biologically available derivative, dihydroberberine, inhibit mitochondrial respiratory complex I: a mechanism for the action of berberine to activate AMP-activated protein kinase and improve insulin action. Diabetes $\mathbf{5 7}$ 1414-1418. (doi:10.2337/db07-1552)

Utting JC, Robins SP, Brandao-Burch A, Orriss IR, Behar J \& Arnett TR 2006 Hypoxia inhibits the growth, differentiation and bone-forming capacity of rat osteoblasts. Experimental Cell Research 312 1693-1702. (doi:10.1016/j.yexcr.2006.02.007)

van der Velde M, Delhanty P, van der Eerden B, van der Lely AJ \& van Leeuwen J 2008 Ghrelin and bone. Vitamins and Hormones 77 239-258.

Viollet B, Andreelli F, Jorgensen SB, Perrin C, Flamez D, Mu J, Wojtaszewski JF, Schuit FC, Birnbaum M, Richter E et al. 2003a Physiological role of AMP-activated protein kinase (AMPK): insights from knockout mouse models. Biochemical Society Transactions 31 216-219. (doi:10.1042/ BST0310216)
Viollet B, Andreelli F, Jorgensen SB, Perrin C, Geloen A, Flamez D, Mu J, Lenzner C, Baud O, Bennoun M et al. 2003b The AMP-activated protein kinase alpha2 catalytic subunit controls whole-body insulin sensitivity. Journal of Clinical Investigation 111 91-98.

Viollet B, Foretz M, Guigas B, Horman S, Dentin R, Bertrand L, Hue L \& Andreelli F 2006 Activation of AMP-activated protein kinase in the liver: a new strategy for the management of metabolic hepatic disorders. Journal of Physiology 574 41-53. (doi:10.1113/jphysiol.2006.108506)

Viollet B, Mounier R, Leclerc J, Yazigi A, Foretz M \& Andreelli F 2007 Targeting AMP-activated protein kinase as a novel therapeutic approach for the treatment of metabolic disorders. Diabetes \& Metabolism 33 395-402. (doi:10.1016/j.diabet.2007.10.004)

Viollet B, Guigas B, Leclerc J, Hebrard S, Lantier L, Mounier R, Andreelli F \& Foretz M 2009a AMP-activated protein kinase in the regulation of hepatic energy metabolism: from physiology to therapeutic perspectives. Acta Physiologica 196 81-98. (doi:10.1111/j.1748-1716.2009.01970.x)

Viollet B, Lantier L, Devin-Leclerc J, Hebrard S, Amouyal C, Mounier R, Foretz M \& Andreelli F 2009b Targeting the AMPK pathway for the treatment of type 2 diabetes. Frontiers in Bioscience 14 3380-3400. (doi:10. $2741 / 3460)$

Vucicevic L, Misirkic M, Janjetovic K, Vilimanovich U, Sudar E, Isenovic E, Prica M, Harhaji-Trajkovic L, Kravic-Stevovic T, Bumbasirevic V et al. 2011 Compound C induces protective autophagy in cancer cells through AMPK inhibition-independent blockade of Akt/mTOR pathway. Autophagy 7 40-50. (doi:10.4161/auto.7.1.13883)

Wan M \& Cao X 2005 BMP signaling in skeletal development. Biochemical and Biophysical Research Communications 328 651-657. (doi:10.1016/j.bbrc. 2004.11.067)

Wan Y, Chong LW \& Evans RM 2007 PPAR-gamma regulates osteoclastogenesis in mice. Nature Medicine 13 1496-1503. (doi:10.1038/ nm1672)

Williams GA, Wang Y, Callon KE, Watson M, Lin JM, Lam JB, Costa JL, Orpe A, Broom N, Naot D et al. 2009 In vitro and in vivo effects of adiponectin on bone. Endocrinology 150 3603-3610. (doi:10.1210/en.20081639)

Woods A, Johnstone SR, Dickerson K, Leiper FC, Fryer LG, Neumann D, Schlattner U, Wallimann T, Carlson M \& Carling D 2003 LKB1 is the upstream kinase in the AMP-activated protein kinase cascade. Current Biology 13 2004-2008. (doi:10.1016/j.cub.2003.10.031)

Xiao B, Sanders MJ, Underwood E, Heath R, Mayer FV, Carmena D, Jing C, Walker PA, Eccleston JF, Haire LF et al. 2011 Structure of mammalian AMPK and its regulation by ADP. Nature 472 230-233. (doi:10.1038/ nature09932)

Yamaguchi N, Kukita T, Li YJ, Kamio N, Fukumoto S, Nonaka K, Ninomiya Y, Hanazawa S \& Yamashita Y 2008 Adiponectin inhibits induction of TNF-alpha/RANKL-stimulated NFATc1 via the AMPK signaling. FEBS Letters 582 451-456. (doi:10.1016/j.febslet.2007.12.037)

Yamashita M, Otsuka F, Mukai T, Yamanaka R, Otani H, Matsumoto Y, Nakamura E, Takano M, Sada KE \& Makino H 2010 Simvastatin inhibits osteoclast differentiation induced by bone morphogenetic protein-2 and RANKL through regulating MAPK, AKT and Src signaling. Regulatory Peptides 162 99-108. (doi:10.1016/j.regpep.2010.03.003)

Yamauchi T, Kamon J, Minokoshi Y, Ito Y, Waki H, Uchida S, Yamashita S, Noda M, Kita S, Ueki K et al. 2002 Adiponectin stimulates glucose utilization and fatty-acid oxidation by activating AMP-activated protein kinase. Nature Medicine 8 1288-1295. (doi:10.1038/nm788)

Yang W, Hong YH, Shen XQ, Frankowski C, Camp HS \& Leff T 2001 Regulation of transcription by AMP-activated protein kinase: phosphorylation of $\mathrm{p} 300$ blocks its interaction with nuclear receptors. Journal of Biological Chemistry 276 38341-38344. (doi:10.1074/jbc.C100316200)

Yu PB, Hong CC, Sachidanandan C, Babitt JL, Deng DY, Hoyng SA, Lin HY, Bloch KD \& Peterson RT 2008 Dorsomorphin inhibits BMP signals required for embryogenesis and iron metabolism. Nature Chemical Biology 4 33-41. (doi:10.1038/nchembio.2007.54)

Zhang BB, Zhou G \& Li C 2009 AMPK: an emerging drug target for diabetes and the metabolic syndrome. Cell Metabolism 9 407-416. (doi:10.1016/j. cmet.2009.03.012) 
Zhao G, Iyengar RR, Judd AS, Cool B, Chiou W, Kifle L, Frevert E, Sham H \& Kym PR 2007 Discovery and SAR development of thienopyridones: a class of small molecule AMPK activators. Bioorganic $\&$ Medicinal Chemistry Letters 17 3254-3257. (doi:10.1016/j.bmcl.2007.04.011)

Zhao J, Yue W, Zhu MJ, Sreejayan N \& Du M 2010 AMP-activated protein kinase (AMPK) cross-talks with canonical Wnt signaling via phosphorylation of beta-catenin at Ser 552. Biochemical and Biophysical Research Communications 395 146-151. (doi:10.1016/j.bbrc. 2010.03.161)

Zhao JX, Yue WF, Zhu MJ \& Du M 2011 AMP-activated protein kinase regulates \{beta\}-catenin transcription via histone deacetylase 5 . Journal of Biological Chemistry 286 16426-16434. (doi:10.1074/jbc.M110. 199372)

Zhen D, Chen Y \& Tang X 2010 Metformin reverses the deleterious effects of high glucose on osteoblast function. Journal of Diabetes and its Complications 24 334-344. (doi:10.1016/j.jdiacomp.2009.05.002)
Zhou G, Myers R, Li Y, Chen Y, Shen X, Fenyk-Melody J, Wu M, Ventre J, Doebber T, Fujii N et al. 2001 Role of AMP-activated protein kinase in mechanism of metformin action. Journal of Clinical Investigation 108 1167-1174.

Zhou G, Sebhat IK \& Zhang BB 2009 AMPK activators - potential therapeutics for metabolic and other diseases. Acta Physiologica 196 175-190. (doi:10.1111/j.1748-1716.2009.01967.x)

Zong H, Ren JM, Young LH, Pypaert M, Mu J, Birnbaum MJ \& Shulman GI 2002 AMP kinase is required for mitochondrial biogenesis in skeletal muscle in response to chronic energy deprivation. PNAS 99 15983-15987. (doi:10.1073/pnas.252625599)

Received in final form 3 August 2011

Accepted 7 September 2011

Made available online as an Accepted Preprint 8 September 2011 